\title{
28 Research Square \\ Effectiveness of Community-level Intervention on Women's Knowledge about Obstetric Fistula in Bench Sheko Zone, Ethiopia
}

\author{
Zerihun Asefa ( $\square$ zerihun.hordofa@ju.edu.et ) \\ Jimma University \\ Feyissa Tolessa \\ Jimma University \\ Muluneh Getachew \\ Jimma University \\ Aster Berhe \\ Jimma University \\ Demisew Amenu \\ Jimma University
}

\section{Research Article}

Keywords: Obstetric Fistula, effectiveness, knowledge level, Women, Bench Sheko Zone, Ethiopia

Posted Date: February 18th, 2021

DOI: https://doi.org/10.21203/rs.3.rs-208656/v1

License: (c) (i) This work is licensed under a Creative Commons Attribution 4.0 International License. Read Full License 


\section{Abstract}

Background: Obstetric fistula is one of the most severe pregnancy-related disabilities. While the condition has disappeared in developed countries, it remains a source of concern in Ethiopia and serves as a proxy indicator of the status of Ethiopian women and the availability and access to quality maternal health services. Therefore, this study aimed to evaluate the effectiveness of a community-level intervention on women's knowledge about obstetric fistula in Bench Sheko Zone, Ethiopia 2020.

Methods: Quasi-experimental design with comparison groups post-test only was employed in Semen Bench as an intervention and Guraferda Woreda as a comparison group of Bench sheko Zone from April, 1-30,2020. A multi-stage sampling technique was employed to select 284 women for intervention and 284 comparison group. Data were collected by using Kobo Collect v1.25.1. The descriptive and binary analysis was done to describe variables and select candidate variables for multivariable regression respectively. Multivariate regression analyses were performed to examine the effects of intervention by using Stata version 16.0.

Result: The intervention group has a significant difference when compared with the counterpart $(p<0.001)$ on women's knowledge of obstetric fistula. Women who have good knowledge about obstetric fistula were $69.7 \%$ and $30.4 \%$ from the intervention and comparison group respectively $(p<0.001)$. Knowledge about obstetric fistula was higher among respondent's who can read \& write $(\mathrm{AOR}=2.707: 95 \% \mathrm{Cl}(1.433-5.686))$, primary level of education $(\mathrm{AOR}=2.073: 95 \% \mathrm{Cl}$ (1.266-3.395)), Secondary and above education (AOR=2.822:95\% Cl (1.338-5.952)) than women who have no formal education. Similarly, heard about obstetric complications (AOR=4.478:95\% $\mathrm{Cl}(2.635-7.610)$ ), history of induced abortion $(A O R=2.347: 95 \% \mathrm{Cl}(1.203-4.576))$, intervention woreda $(A O R=2.707: 95 \% \mathrm{Cl}(1.771-4.138))$ attending pregnant women conference $(A O R=0.06: 95 \% \mathrm{Cl}(0.02-0.19))$, age at first pregnancy greater than 20 years $(A O R=1.7295 \% \mathrm{Cl}(1.10-2.68))$ were the factors associated with knowledge of obstetric fistula.

Conclusion: Measurable differences between intervention and comparison woreda in terms of women's knowledge of obstetric fistula was observed. Therefore, Community based intervention can increase women's knowledge and encourage the use of essential obstetric services.

\section{Background}

One of the most extreme and devastating childbirth injuries is obstetric fistula. Long, obstructed labor without access to prompt, high-quality medical attention is caused by a hole between the birth cane and the bladder and/or rectum. It leaks urine, feces, or both to women and also contributes to chronic medical conditions, depression, social alienation, and deep poverty. (1).

Obstetric fistula prevention techniques, according to the World Health Organization (WHO), include delaying the age of first pregnancy; stopping unsafe conventional practices; and prompt access to obstetric treatment. Obstetric fistula prevention and management lead to Sustainable Development Target 3 of improving maternal health (2). For a long time, obstetric fistula has been known to be both preventable and often treatable, and this condition continues to affect a large number of young women in the developing world, a situation which creates problems with both economic resources and health services, especially in the area of maternal health. However, increased access to sufficient prenatal and emergency obstetric care would enable more women to avoid obstructed labor that can sometimes contribute to fistula (3).

The World Health Organization (WHO) reports that over 300 million women are currently suffering from short-term or long-term pregnancy or childbirth complications, with about 20 million new cases occurring worldwide each year. Infertility, extreme anemia, uterine prolapse, and vaginal fistula are problems. About 50,000-100,000 women are 
estimated to develop obstetric fistula annually, with at least 33,000 of these in sub-Saharan Africa (2). In all developing countries, obstetric fistulas are found. The majority of obstetric fistulas, however, are limited to the "fistula belt" from Mauritania to Eritrea and in the developing countries of Middle East Asia throughout the northern half of sub-Saharan Africa (4).

While the situation in developed countries has ended, it remains a source of concern in Ethiopia and serves as a proxy for the status of women in Ethiopia and the availability and accessibility of quality maternal health services. The most debilitating morbidity in pregnancy is obstetric fistula. It mostly affects young, disadvantaged women who lack the resources for their families to access quality maternal care. In remote villages, several of these women remain concealed. As demand is much greater than the capacity of existing facilities, those who have access to surgical repair face long waits. Repair systems do not exist in certain places (5).

USAID 2013 issue analysis reports that there are between 36,000 and 39,000 women currently living with obstetric fistula and that every year there are between 3,300 and 3,750 new cases of obstetric fistula in Ethiopia. In Ethiopia, data on birth outcomes is not yet uniformly or routinely available due to the low rate of institutional deliveries, so this data was generated by modeling estimates (6).

Several barriers to the treatment of fistula that function at the individual, neighborhood, and national levels. Therefore, the effective treatment of obstetric fistula may require many challenges to be tackled, including depression, stigma and shame, lack of community-based referral systems, transport difficulties, imbalances of gender power, reintegration of the community, and the conflicting political objectives. A lack of fistula awareness and knowledge is probably one of the most daunting obstacles (7). While in 2014, under the slogan "Ending obstetric fistula and Transforming Lives by 2020," Ethiopia initiated a five-year program on obstetric fistula elimination. The Federal Ministry of Health is leading the development of an action plan to accelerate obstetric fistula elimination by 2020(8).

As the implementing partner, the Jimma University Fistula Care Project has focused on obstetric fistula prevention and treatment. Training health professionals and key stakeholders of communities in efforts to improve awareness about obstetric fistula prevention over the past seven years. The present study is, therefore, aimed Effectiveness of communitylevel intervention on women's knowledge about obstetric Fistula.

\section{Methods}

\section{Study design and area}

A quasi-experimental design with comparison groups post-test only was used. Intervention areas were purposively sampled to focus on kebele in each woreda that had exposure to the intervention. A classic method for supporting a counterfactual inference is to add a comparison group that received no intervention, with the comparison group selected to be as similar as possible to the intervention group. Indicators were selected by referring to the 2015 strategic plan(8), WHO Guideline (9). Finally, 22 indicators were selected. The evaluation was conducted in Semen Bench and Guraferda Woreda of Bench Sheko Zone of Southern Nations Nationalities and peoples Region, Ethiopia between April 1-30/ 2020

\section{Sample Size determination and sampling technique}

The sample size was calculated using two population proportions formula by using G-power v3.1 software with the following assumption (10): Difference between two independent proportions by one-to-one allocation ratio and $80 \%$ power was used to detect a $15 \%$ difference in the proportion of women with knowledge of obstetric fistula. Then after considering a 5\% non-response rate and design effects of 2, the final sample size was 564(282 from intervention and 
282 from the comparison group). A multi-stage sampling technique was employed. In the first stage for both groups, $30 \%$ of kebeles were selected by a simple random sampling technique. The sample size was proportionally allocated for each kebeles.

\section{Data collection tools}

A structured questioner was adapted from previously conducted studies in Eritrea, Guinea, Awi Zone, North West, Ethiopia for the sociodemographic and knowledge part of the study (10-12). The questionnaire includes three parts, background information, obstetric information, and, questions on obstetric fistula. Knowledge of obstetric fistula was assessed by evaluating responses to 22 questions on obstetric fistula including the cause, risk factors, symptoms, prevention method, and treatment of obstetric fistula.

Data Collectors were B.Sc. health professionals and supervisors were MSc Health Professionals outside of the study area to minimize bias. Data collectors and supervisors were trained for two days to be familiar with all types of data, tools, and data collection methods and objectives and one-day practical sessions on Kobo Collect. Data collection was done through face-to-face interviews by using Kobo collect. Female house head was primary respondents and in the absence of them, females age greater than 18 were interviewed. if both not present at the time of data collection revisit was made at least two times.

\section{Intervention}

The intervention(training) was given for key community leaders as maternal health volunteers. Key community leaders include kebele manager, religious leaders, health extensions workers, school director, Health Developmental Army (HDAs), Women and children affairs from kebele, district and zone, and health providers, woreda MCH Head, health center $\mathrm{MCH}$ focal person were trained at woreda level for 2 days. The key elements of the intervention were increasing obstetric fistula identification, prevention, and treatment through women participation in pregnant women conferences, educating pregnant women and their husbands, and key community during home visits on early and complete ANC visits.

\section{Data quality control}

The data collection tool was translated into Amharic language and translated back to English to check its consistency. A pre-test was done on $5 \%$ of participants at Sheko woreda and modifications were made in the final version of the questionnaire. During data collection, completeness and consistency of information were checked by the supervisor and principal investigator daily. In this study, the reliability of knowledge measuring items was checked by calculating the Cronbach alpha (a). The Cronbach alpha, inter-item consistency (Cronbach alpha) for knowledge measuring tools of 22 items was 0.76 . In light of the above-mentioned Cronbach's Alpha values, the measuring instrument is deemed reliable for both intervention and comparison groups.

\section{Data processing and analysis}

All data were electronically collected on-site and uploaded daily to the kobo server database using kobo collect v1.25.1(kobotoolbox.org). Database content was checked for missing answers, duplications, and inconsistencies. Then data were exported to Stata software version 16.0 for further analysis. Descriptive statistics were used to determine the 
frequency, mean, and proportions of variables. In bivariate logistics regression, a variable whose $p \leq 0.25$ was considered as a candidate for multivariable logistic regression analysis.

And variables having $\mathrm{p} \leq 0.05$ after multivariable logistic regression analysis were considered as independent predictors for knowledge. Statistical significance was assessed using the chi-square test, odds ratios, and $95 \% \mathrm{Cl}, \mathrm{p}$ values less than 0.05 used as cut off point for Statistical significance. Hosmer-Lemeshow goodness of fit was used to check the goodness of the applied models (0.48). and the model adequately fits the data.

\section{Operational definitions}

Knowledge: The knowledge was measured by 22 items. Mean was calculated to categorize it into two. Those who scored above the mean were considered as having good knowledge, and those who scored below the mean were considered as poor knowledge. Those women who define obstetric fistula by describing at least one way were taken as know the definition of obstetric fistula. Those women who list at least one cause of obstetric fistula was taken as know the cause of obstetric fistula. Those women who list at least two risk factors of obstetric fistula were taken as a known risk of obstetric fistula. Those women who list at least two symptoms of obstetric fistula were taken as know the symptoms of obstetric fistula. Those women who list at least two prevention methods of obstetric fistula were taken as know the prevention method of obstetric fistula. Those women who answer at least two questions about obstetric fistula were taken as know obstetric fistula will be treated.

\section{Results}

\section{Sociodemographic Characteristics}

Five hundred eighteen women (259 respondents from the intervention \& 259 respondents from control groups) participated in the study with a response rate of $91.8 \%$. The mean age of participants was $32.0 \pm 9.8$ and $30.9 \pm 8.5$ years old for the intervention and comparison group respectively. The mean age at marriage was 20.5 vs 19.2 years in the intervention and comparison group. One-hundred five (40.5\%) and 155(59.8\%) had not attended formal education among intervention and comparison groups respectively. (Table 1). 
Table 1

Socio-demographic characteristics of participants in Bench Sheko Zone, Ethiopia,2020 $(n=518)$.

\begin{tabular}{|c|c|c|c|c|}
\hline Variables & & $\begin{array}{l}\text { Intervention group } \\
(\mathrm{n}=\%)\end{array}$ & $\begin{array}{l}\text { Comparison group } \\
(\mathrm{n}=\%)\end{array}$ & $\begin{array}{l}\mathrm{p}- \\
\text { value }\end{array}$ \\
\hline \multirow[t]{8}{*}{ Age group } & $15-19$ & $3(0.4 \%)$ & $6(2.3 \%)$ & 0.222 \\
\hline & $20-24$ & $43(8.3 \%)$ & $48(18.5 \%)$ & \\
\hline & $25-29$ & $70(27 \%)$ & $62(23.9 \%)$ & \\
\hline & $30-34$ & $54(20 \%)$ & $63(24.3 \%)$ & \\
\hline & $35-39$ & $47(18.1 \%)$ & $54(20.8 \%)$ & \\
\hline & $40-44$ & $10(3.9 \%)$ & $11(4.2 \%)$ & \\
\hline & $45-49$ & $8(3.1 \%)$ & $5(1.9 \%)$ & \\
\hline & $>49$ & $24(9.3 \%)$ & $10(3.9 \%)$ & \\
\hline \multirow[t]{4}{*}{ Religion } & Orthodox & $60(23.2 \%)$ & $134(51.7 \%)$ & $\begin{array}{l}<.001 \\
0.01\end{array}$ \\
\hline & Protestant & $186(71.8 \%)$ & $71(27.4 \%)$ & \\
\hline & Muslim & $2(0.8 \%)$ & $38(14.7 \%)$ & \\
\hline & Catholic & $11(4.2 \%)$ & $16(6.2 \%)$ & \\
\hline \multirow[t]{4}{*}{ Marital status } & Married & $249(96.1 \%)$ & $242(93.4 \%)$ & 0.178 \\
\hline & Single & $7(2.7 \%)$ & $8(3.1 \%)$ & \\
\hline & Divorced & $1(0.4 \%)$ & $8(3 \%)$ & \\
\hline & Widowed & $2(0.8)$ & $1(0.4 \%)$ & \\
\hline \multirow[t]{4}{*}{ Occupational Status } & House Wife & $212(81.9 \%)$ & $225(86.7 \%)$ & 0.047 \\
\hline & Employed & $20(7.7 \%)$ & $12(4.6 \%)$ & \\
\hline & Marchant & $19(7.3 \%)$ & $21(8.1 \%)$ & \\
\hline & Student & $8(3.1 \%)$ & $1(0.4 \%)$ & \\
\hline \multirow[t]{4}{*}{ Educational status } & No formal education & $105(40.5 \%)$ & $155(59.8 \%)$ & $\dot{0}_{0.001}^{<}$ \\
\hline & Read \& write only & $31(12 \%)$ & $22(8.5 \%)$ & \\
\hline & Primary School & $67(25.9 \%)$ & $91(35.1 \%)$ & \\
\hline & $\begin{array}{l}\text { Secondary school and } \\
\text { Above }\end{array}$ & $32(12.4 \%)$ & $15(5.8 \%)$ & \\
\hline \multirow{4}{*}{$\begin{array}{l}\text { Husband Occupational } \\
\text { Status }\end{array}$} & Farmer & $199(76.8 \%)$ & $220(84.9 \%)$ & 0.002 \\
\hline & Employed & $34(13.1 \%)$ & $16(6.2 \%)$ & \\
\hline & Marchant & 19(7.3\%) & $23(8.9 \%)$ & \\
\hline & Student & $7(2.7 \%)$ & $0(0 \%)$ & \\
\hline
\end{tabular}




\begin{tabular}{|lllll|}
\hline Variables & & $\begin{array}{l}\text { Intervention group } \\
(\mathbf{n}=\%)\end{array}$ & $\begin{array}{l}\text { Comparison group } \\
(\mathbf{n = \%})\end{array}$ & $\begin{array}{c}\text { p- } \\
\text { value }\end{array}$ \\
\hline $\begin{array}{l}\text { Husband Educational } \\
\text { Status }\end{array}$ & No formal education & $77(29.7 \%)$ & $143(55.2 \%)$ & $<$ \\
\hline & Read \& write only & $32(12.4 \%)$ & $47(18.1 \%)$ & \\
\hline & $\begin{array}{l}\text { Primary education } \\
\text { Secondary school and } \\
\text { above }\end{array}$ & $97(37.5 \%)$ & $45(17.4 \%)$ \\
\hline
\end{tabular}

\section{Obstetric Factors}

The proportion of women who heard about obstetric complications was 197 (76.1\%) and 146(56.4\%) from the intervention and comparison group respectively. About twenty-seven (10.4\%) and 22(8.5\%) of the women have a history of induced abortion from intervention and comparison groups respectively. Levels of birth preparedness and complication readiness were $188(72.6 \%)$ and $111(42.9 \%)$ in the intervention and comparison group respectively. Heard about obstetric complication intervention area (76.1\% vs $56.4 \%) \mathrm{P}<0.001$, Family planning in intervention area (81.2\% vs $69.1 \%$ ) $\mathrm{P}<0.001,1-2$ Delivery(C69.1\%) $\mathrm{P}<0.001$, ANC in Intervention area (68.7\% vs $61.8 \%) \mathrm{P}<0.001$, Know the benefits of Institutional delivery in Intervention area (73.4\% vs 42.9\%) $\mathrm{P}<0.001$, know danger sign in Intervention area (74.1\% vs 54.8\%) P < 0.001, know Birth preparedness and complication, read ness in Intervention area (72.6\% vs $42.9 \%)$ $\mathrm{P}<0.001$, Given these differences, we adjusted in the final analyses. And Other Characteristics of respondents about obstetrical factors were similar in both groups. (Table 2) 
Table 2

Characteristics of respondents about obstetrical factors in Bench Sheko Zone, Ethiopia,2020 ( $n=518)$.

\begin{tabular}{|c|c|c|c|c|}
\hline Variables & & $\begin{array}{l}\text { Intervention group } \\
(\mathrm{n}=\%)\end{array}$ & $\begin{array}{l}\text { Comparison group } \\
(n=\%)\end{array}$ & $\begin{array}{l}\mathrm{p}- \\
\text { value }\end{array}$ \\
\hline \multirow[t]{2}{*}{ Heard about obstetric complication } & No & $62(23.9 \%)$ & $113(43.6 \%)$ & $<.001$ \\
\hline & Yes & 197(76.1\%) & $146(56.4 \%)$ & \\
\hline \multirow[t]{2}{*}{ Age at first pregnancy } & $<20$ years & $151(58.3 \%)$ & $169(65.3 \%)$ & 0.064 \\
\hline & $>20$ Years & $101(39.0 \%)$ & $82(31.7 \%)$ & \\
\hline \multirow[t]{2}{*}{ History of induced abortion } & No & 232(89.6\%) & $237(91.5 \%)$ & 0.885 \\
\hline & Yes & $27(10.4 \%)$ & $22(8.5 \%)$ & \\
\hline \multirow[t]{2}{*}{ History of Birth related complication } & No & $229(88.4 \%)$ & $230(88.8 \%)$ & 0.787 \\
\hline & Yes & $30(11.6 \%)$ & $29(11.2 \%)$ & \\
\hline \multirow[t]{2}{*}{ Family planning } & No & $49(18.9 \%)$ & $80(30.9 \%)$ & 0.001 \\
\hline & Yes & $210(81.2 \%)$ & $179(69.1 \%)$ & \\
\hline \multirow[t]{2}{*}{ Ever pregnant } & No & $12(4.6 \%)$ & $15(5.8 \%)$ & 0.838 \\
\hline & Yes & $247(95.4 \%)$ & $244(94.2 \%)$ & \\
\hline \multirow[t]{3}{*}{ Number of Delivery } & 0 & $43(16.6 \%)$ & $50(19.3 \%)$ & 0.010 \\
\hline & $1-2$ & 164(63.3\%) & $179(69.1 \%)$ & \\
\hline & $>5$ & $45(17.4 \%)$ & $22(8.5 \%)$ & \\
\hline \multirow[t]{2}{*}{ ANC } & No & $81(31.3 \%)$ & $99(38.2 \%)$ & 0.016 \\
\hline & Yes & $178(68.7 \%)$ & $160(61.8 \%)$ & \\
\hline \multirow[t]{2}{*}{ Know the benefits of Institutional delivery } & No & $69(26.6 \%)$ & $148(57.1 \%)$ & $<.001$ \\
\hline & Yes & $190(73.4 \%)$ & $111(42.9 \%)$ & \\
\hline \multirow[t]{2}{*}{ Know danger sign } & No & $67(25.9 \%)$ & $117(45.2 \%)$ & $<.001$ \\
\hline & Yes & 192(74.1\%) & $142(54.8 \%)$ & \\
\hline \multirow[t]{3}{*}{$\begin{array}{l}\text { know Birth preparedness and complication } \\
\text { read ness }\end{array}$} & No & $71(27.4 \%)$ & $148(57.1 \%)$ & $<.001$ \\
\hline & Yes & $188(72.6 \%)$ & $111(42.9 \%)$ & \\
\hline & 0 & $9(3.5 \%)$ & $11(4.3 \%)$ & 0.047 \\
\hline \multirow[t]{2}{*}{ Place of delivery } & Home & $62(25.4 \%)$ & $114(47.1 \%)$ & $<.001$ \\
\hline & $\begin{array}{l}\text { Health } \\
\text { Facility }\end{array}$ & $182(74.6 \%)$ & $128(52.9 \%)$ & \\
\hline Distance from the nearest Health facility & $\begin{array}{l}<30 \\
\text { Minutes }\end{array}$ & $11(4.2 \%)$ & $30(11.6 \%)$ & $\begin{array}{l}<.001 \\
0.00\end{array}$ \\
\hline
\end{tabular}




\begin{tabular}{|lllll|}
\hline Variables & & $\begin{array}{l}\text { Intervention group } \\
(\mathbf{n}=\%)\end{array}$ & $\begin{array}{l}\text { Comparison group } \\
(\mathbf{n}=\%)\end{array}$ & $\begin{array}{l}\mathbf{p} \text { - } \\
\text { value }\end{array}$ \\
\hline & $>30$ & $248(95.8 \%)$ & $229(88.4 \%)$ \\
& & & \\
\hline
\end{tabular}

\section{Knowledge of obstetric fistula}

Concerning the source of knowledge most commonly cited sources about fistula were health extension workers (63.7\%) with P-value < 0.001), Media (23.8\%), Family \& friends (28.5\%), and women who had been treated for fistula (4.7\%). One hundred twenty-three (49.4\%) of those in intervention villages were able to list at least one cause of the obstetric fistula, compared with $18.4 \%$ in comparison woreda. Among women who heard about obstetric fistula, the proportion of women who perceive at least two or more risk factors of the obstetric fistula was 139 (53.7\%) versus $43(16.6 \%)$ of the intervention group and a comparison group respectively. percentage of women who able to cite 2 or more symptoms of obstetric fistula were $140(54.1 \%)$ versus $53(20.5 \%)$ of the respondents from the intervention and the comparison group. Concerning obstetric fistula prevention, $135(52.1 \%)$ versus $35(18.9 \%)$ of participants were able to cite 1 or more ways to prevent fistula from the intervention and the comparison group. This study shows that the proportion of women who know that obstetric fistula will be treated as 124(47.9\%) from the intervention group and 38(14.7\%) respondents from the comparison group. (Table 3). 
Table 3

Participants' characteristics of knowledge on obstetric fistula in Bench Sheko Zone, Ethiopia,2020 $(n=518)$.

\begin{tabular}{|c|c|c|c|c|c|}
\hline \multicolumn{3}{|l|}{ Variables } & $\begin{array}{l}\text { Intervention } \\
\text { Group }(n=\%)\end{array}$ & $\begin{array}{l}\text { Comparison } \\
\text { Group }(n=\%)\end{array}$ & P_value \\
\hline Heard obstetric fistula & \multicolumn{2}{|l|}{ Ever heard obstetric fistula } & $140(54.1)$ & $67(25.9)$ & $<0.001$ \\
\hline \multirow[t]{4}{*}{ Source of Information } & \multicolumn{2}{|l|}{ Health extension worker } & 123(63.7) & $34(17.6)$ & 0.004 \\
\hline & \multicolumn{2}{|l|}{ Family and friend } & $55(28.5)$ & $22(11.4)$ & 0.079 \\
\hline & \multicolumn{2}{|l|}{ School } & 15(7.8) & $7(3.6)$ & 0.568 \\
\hline & \multicolumn{2}{|l|}{ Media } & $46(23.8)$ & $5(2.6)$ & 0.076 \\
\hline \multirow{3}{*}{$\begin{array}{l}\text { How to describe } \\
\text { obstetric fistula }\end{array}$} & \multicolumn{2}{|l|}{ Continuous leakage of urine } & $114(81.4)$ & $40(59.7)$ & 0.001 \\
\hline & \multicolumn{2}{|c|}{$\begin{array}{l}\text { Continuous leakage of urine and or } \\
\text { feces }\end{array}$} & $17(12)$ & 23(34.3) & \\
\hline & \multicolumn{2}{|l|}{ The continuous odor of urine } & $9(6.4)$ & $4(6)$ & \\
\hline \multirow[t]{4}{*}{ Cause } & \multirow{2}{*}{$\begin{array}{l}\text { Knows prolonged labor as a } \\
\text { cause of fistula }\end{array}$} & No & $34(24.3)$ & $24(35.8)$ & 0.084 \\
\hline & & Yes & $106(75.7)$ & $43(64.2)$ & \\
\hline & \multirow{2}{*}{$\begin{array}{l}\text { Knows sexual violence as a } \\
\text { cause of fistula }\end{array}$} & No & $59(42.1)$ & $38(56.7)$ & 0.049 \\
\hline & & Yes & $81(57.9)$ & $29(43.3)$ & \\
\hline \multirow[t]{5}{*}{ Risk factors } & \multicolumn{2}{|l|}{ Early Marriage } & $87(62.1 \%)$ & $35(52.2 \%)$ & 0.175 \\
\hline & \multicolumn{2}{|l|}{ Early Pregnancy } & $60(42.9 \%)$ & $38(56.7 \%)$ & 0.062 \\
\hline & \multicolumn{2}{|l|}{ Home delivery } & $111(79.3 \%)$ & $31(46.3 \%)$ & $<0.001$ \\
\hline & \multicolumn{2}{|l|}{ Female Genital Mutilation } & $45(32.1 \%)$ & $8(11.9 \%)$ & 0.002 \\
\hline & \multicolumn{2}{|l|}{ Prolonged labor } & $22(15.7 \%)$ & $3(4.5 \%)$ & 0.020 \\
\hline \multirow[t]{4}{*}{ Symptoms } & \multicolumn{2}{|l|}{ Unable to control urine } & 131(93.6) & $57(85.1)$ & 0.048 \\
\hline & \multicolumn{2}{|l|}{ Unable to control feces } & 122(87.1) & $32(47.8)$ & 0.018 \\
\hline & \multicolumn{2}{|l|}{ Unable to control urine and feces } & $85(60.7)$ & $29(43.3)$ & 0.048 \\
\hline & \multicolumn{2}{|l|}{ Bleeding and pain during sex } & $9(3.5)$ & $10(14.9)$ & 0.005 \\
\hline \multirow[t]{8}{*}{ Prevention Method } & \multirow{2}{*}{$\begin{array}{l}\text { Delaying the age of early } \\
\text { marriage }\end{array}$} & No & $61(45.2)$ & $10(28.6)$ & 0.002 \\
\hline & & Yes & $74(54.8)$ & $39(79.6)$ & \\
\hline & \multirow[t]{2}{*}{ Cessation of Early pregnancy } & No & $51(37.8)$ & $26(74.3)$ & 0.000 \\
\hline & & Yes & $84(62.2)$ & 15(30.6) & \\
\hline & \multirow{2}{*}{$\begin{array}{l}\text { Timely access to the health } \\
\text { facility }\end{array}$} & No & $96(71.1)$ & $27(77.1)$ & 0.041 \\
\hline & & Yes & $39(28.9)$ & $22(44.9)$ & \\
\hline & \multirow{2}{*}{$\begin{array}{l}\text { Delivery with a skilled birth } \\
\text { attendant }\end{array}$} & No & $63(45)$ & $38(71.7)$ & 0.000 \\
\hline & & Yes & $77(50)$ & 18(26.9) & \\
\hline
\end{tabular}




\begin{tabular}{|c|c|c|c|c|c|}
\hline \multicolumn{3}{|l|}{ Variables } & \multirow{2}{*}{$\begin{array}{l}\text { Intervention } \\
\text { Group (n=\%) } \\
69(49.3)\end{array}$} & \multirow{2}{*}{$\begin{array}{l}\begin{array}{l}\text { Comparison } \\
\text { Group }(n=\%)\end{array} \\
34(64.2)\end{array}$} & \multirow{2}{*}{$\begin{array}{l}\text { P_value } \\
0.005\end{array}$} \\
\hline & Health Facility Delivery & No & & & \\
\hline & & Yes & $71(50.7)$ & $20(29.9)$ & \\
\hline \multirow[t]{6}{*}{ Treatment } & Know OF will be treated & No & $14(10)$ & $26(38.8)$ & $<0.001$ \\
\hline & & Yes & $126(90.0)$ & $41(61.2)$ & \\
\hline & Know cured OF women & No & 115(82.1) & $53(79.1)$ & 0.601 \\
\hline & & Yes & $25(17.9)$ & $14(20.9)$ & \\
\hline & Know fistula repair center & No & $71(50.7)$ & $40(59.7)$ & 0.225 \\
\hline & & Yes & $69(49.3)$ & $27(40.3)$ & \\
\hline
\end{tabular}

\section{Overall knowledge status of women on obstetric fistula}

According to this study, 140(69.7\%) and 61(30.4\%) have good knowledge of obstetric fistula while 119(37.5\%) and $198(62.5 \%)$ have poor knowledge from the intervention and comparison group respectively. And the overall knowledge status of women difference between intervention and comparison is statically significant at $p$-value $<0.001$. (Fig. 1)

\section{Determinants of women knowledge status on obstetric fistula}

The bivariate analysis result shows the educational status of women, age at first pregnancy, obstetric complication, history of induced abortion, modern contraceptive use, ANC for last pregnancy, know benefits of institutional delivery, know danger sign during pregnancy and childbirth, know birth preparedness and complication readiness, place of delivery and Pregnant women conference were found to have a significant association (Table 4).

In Multivariate analysis, the result showed a significant association between age at first pregnancy, pregnant women conference, heard about Obstetric complications, History of induced abortion, Educational status of women, and intervention. Women who were from intervention woreda have 2.7 of respondents from the intervention woreda have more likely to have good knowledge of obstetric fistula than those from comparison woreda $(\mathrm{AOR}=2.707: 95 \% \mathrm{Cl}$ $(1.771-4.138))$.

Women who can read \& write only were 2.7 more likely to have knowledge than women who have no formal education $(A O R=2.707: 95 \% \mathrm{Cl}(1.433-5.686))$. Similarly, women who have a primary level of education were 2 times more likely to have knowledge than women who are no formal education ( $A O R=2.073: 95 \% \mathrm{Cl}(1.266-3.395)$. likewise, women who have high school and above 2.8 times more likely to have knowledge than women who have no formal education (AOR $=2.822: 95 \% \mathrm{Cl}(1.338-5.952)$. Also, this study shows women who heard about obstetric complications are 4.5 times more likely to have knowledge of obstetric fistula than those who haven't heard about obstetric complications (AOR = $4.478: 95 \% \mathrm{Cl}(2.635-7.610))$.

Those who had a history of induced abortion were 2.4 times more likely to have knowledge of obstetrics fistula prevention than women who have no history of induced abortion ( $A O R=2.347: 95 \% \mathrm{Cl}(1.203-4.576)$ ). Similarly, those who had a greater than 20 years of age at first pregnancy were 1.7 times more likely to have knowledge of obstetrics fistula prevention than less than 20 years of age at first pregnancy $(A O R=1.715: 95 \% \mathrm{Cl}(1.0979-2.679)$ ). 
Those who were participated in pregnant women conferences were 18 times more likely to have knowledge of obstetrics fistula than those not participating in pregnant women conferences (AOR $=9.6: 95 \% \mathrm{Cl}(3.26-28.35)$ ).

Table 4

Multivariate logistic Regression analysis showing the impact of selected associated factors of obstetric fistula among women in Bench Sheko Zone, Ethiopia,2020 ( $n=518)$.

\begin{tabular}{|c|c|c|c|c|c|c|c|}
\hline \multicolumn{2}{|l|}{ Variables } & $\begin{array}{l}\text { Good } \\
\text { Knowledge }\end{array}$ & $\begin{array}{l}\text { Poor } \\
\text { Knowledge }\end{array}$ & \multirow{2}{*}{$\begin{array}{l}\text { Unadjusted } \\
\text { OR (95\% Cl) }\end{array}$} & \multirow[t]{2}{*}{ P-value } & \multirow{2}{*}{$\begin{array}{l}\text { Adjusted } \\
\text { OR }(95 \% \\
\text { Cl) }\end{array}$} & \multirow[t]{2}{*}{ P-value } \\
\hline Study Area & $\begin{array}{l}\text { comparison } \\
\text { Group* }\end{array}$ & $61(30.4 \%)$ & $198(62.5 \%)$ & & & & \\
\hline & $\begin{array}{l}\text { Intervention } \\
\text { Group }\end{array}$ & $140(69.7 \%)$ & $119(37.5 \%)$ & $\begin{array}{l}3.82(2.62- \\
5.57)\end{array}$ & 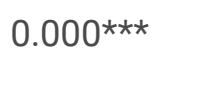 & $\begin{array}{l}2.71(1.77- \\
4.14)\end{array}$ & $<.001 * * *$ \\
\hline \multirow[t]{4}{*}{$\begin{array}{l}\text { Educational } \\
\text { Status }\end{array}$} & $\begin{array}{l}\text { No formal } \\
\text { education* }\end{array}$ & $71(35 \%)$ & $189(59.6 \%)$ & & & & \\
\hline & $\begin{array}{l}\text { Read \& } \\
\text { write only }\end{array}$ & $28(13.9 \%)$ & $25(7.9 \%)$ & $25(7.9 \%)$ & $\begin{array}{l}2.981(1.63- \\
5.46)\end{array}$ & $\begin{array}{l}2.85(1.43- \\
5.69)\end{array}$ & $0.003 * * *$ \\
\hline & $\begin{array}{l}\text { Primary } \\
\text { education }\end{array}$ & $74(36.8 \%)$ & $85(26.5 \%)$ & $85(26.5 \%)$ & $\begin{array}{l}2.345(1.55- \\
3.55)\end{array}$ & $\begin{array}{l}2.07(1.27- \\
3.40\end{array}$ & $0.004 * * *$ \\
\hline & $\begin{array}{l}\text { Secondary } \\
\text { school \& } \\
\text { above }\end{array}$ & $28(13.9 \%)$ & $19(6 \%)$ & $\begin{array}{l}3.92(2.06- \\
7.46)\end{array}$ & 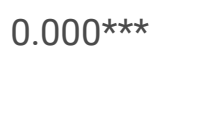 & $\begin{array}{l}2.82(1.34- \\
5.95)\end{array}$ & $0.006^{* * *}$ \\
\hline \multirow{2}{*}{$\begin{array}{l}\text { Heard } \\
\text { Obstetric } \\
\text { complication }\end{array}$} & No* & $30(14.9 \%)$ & $147(46.4 \%)$ & & & & \\
\hline & Yes & $171(85.1 \%)$ & $170(53.6 \%)$ & $\begin{array}{l}4.929(3.15- \\
7.70)\end{array}$ & $0.000 * \star \star$ & $\begin{array}{l}4.48(2.63- \\
7.61)\end{array}$ & $<.001 * * *$ \\
\hline \multirow[t]{2}{*}{ History of IA } & No* & $170(84.6 \%)$ & 295(93.1\%) & & & & \\
\hline & Yes & 31 (15.4\%) & $22(6.9 \%)$ & $\begin{array}{l}2.24(1.24- \\
4.06)\end{array}$ & $0.008^{\star \star \star}$ & $\begin{array}{l}2.35(1.20- \\
4.58)\end{array}$ & $0.012^{* *}$ \\
\hline \multirow[t]{2}{*}{$\begin{array}{l}\text { Age at first } \\
\text { pregnancy }\end{array}$} & $\begin{array}{l}=<20 \\
\text { Years* }\end{array}$ & $208(68.2 \%$ & 114(57.3) & & & & \\
\hline & $>20$ Years & $85(42.7 \%)$ & $97(31.8 \%)$ & $\begin{array}{l}1.599 \\
(1.104- \\
2.315)\end{array}$ & $0.013^{\star \star \star}$ & $\begin{array}{l}1.72(1.10- \\
2.68)\end{array}$ & $0.018^{* *}$ \\
\hline \multirow[t]{2}{*}{ PWC } & No* & 179(89.1\%) & $7(2.7 \%)$ & & & & \\
\hline & Yes & $22(11 \%)$ & $4(1.3 \%)$ & $\begin{array}{l}9.6(3.26- \\
28.35)\end{array}$ & $0.000 * \star \star$ & $\begin{array}{l}18.1(5.41- \\
60.74\end{array}$ & $<.001^{* * *}$ \\
\hline
\end{tabular}

\section{Discussion}

This finding shows that women who have ever heard and describe obstetric fistula were $54.1 \%$ and $25.9 \%$ from intervention and comparison groups respectively. This finding was higher than the study done in Burkina Faso, Guinea which is $36 \%$ and $34 \%(13,14)$ The difference might be due to the sample size, and the year of the study.

These findings also underscore that women who had heard and were able to describe obstetric fistula, $49.5 \%$ of those in the intervention area were able to list at least one cause of the condition, compared with $18.5 \%$ in comparison woreda. 
These findings are consistent with the evaluation of community-level fistula prevention interventions in Guinea which show that women who had heard of and were able to describe obstetric fistula, $48 \%$ of those in intervention villages were able to list at least two cause of the condition, compared with $32 \%$ in comparison villages (14).

This evaluation finding highlights the importance of increased attention to the risk of obstetric fistula, and among women who had heard of obstetric fistula; $46.3 \%$ from the intervention group and $15.1 \%$ from the comparison group knew at least two risk factors of obstetric fistula. This finding is consistent with a study conducted in Ghana among prenatal clinic attendees show that perceived risk factors for obstetric fistula included home delivery (80.5\%), prolonged labor $(67.3 \%)$, teenage pregnancy and delivery $(50.4 \%)(15)$. The possible differences in the content of the intervention provided to the intervention woreda may have more effective in their knowledge raising activities whether through home visits/pregnancy women conference, community meeting, or through other awareness-raising activities, such as health education talks and community discussions.

Our finding shows that about half $52.1 \%$ of participants from the intervention group and $18.9 \%$ from the comparison group were able to cite one or more ways to prevent obstetric fistula. The present evaluation finding is lower than a similar evaluation done in Guinea which reported that $96 \%$ vs $90 \%$ of women from the intervention and comparison area were able to list at least one way to prevent obstetric fistula(14). This difference might be due to, study period, sociodemographic, including a diverse study population.

This finding revealed that knowledge of women on the treatment of obstetric fistula shows that the majority $48 \%$ from the intervention group and only a few $15 \%$ of respondents from the comparison group know that obstetric fistula will be treated. This study was consistent with a study conducted in Ghana on Knowledge of obstetric fistula among prenatal clinic attendees on treatment for obstetric fistula show that two-thirds $66.7 \%$ of the women who knew about obstetric fistula agreed that the condition could be treated (15).

According to this study, the intervention effect caused a statistically significant difference in women obstetric fistula knowledge as evidenced by the fact that respondents who received a community-based intervention had a good knowledge than that of those who did not have any intervention. The finding revealed that the overall knowledge status of women on obstetric fistula was $69.7 \%$ and $30.4 \%$ were good knowledge and $37.5 \%$ and $62.5 \%$ were poor knowledge for intervention and comparison group respectively. This finding is similar to a study done in Ghana which shows that from mothers who had heard of obstetric fistula, $37.2 \%$ had poor knowledge, $62.8 \%$ had good knowledge (15). This finding suggests that community intervention may have a beneficial effect on women's knowledge of obstetric fistula.

Our study shows that knowledge of obstetric fistula was higher among respondents who read \& write only were twopoint eight higher than those who didn't attend formal education. women who have a primary level of education are two times more likely to know women who are no formal education. women who have a secondary school and above were two points eight times more likely to know women who have no formal education. This study agrees with the study done in Burkina Faso on obstetric fistula knowledge (13). This might be those attending formal education have greater opportunities to get information, asking, and getting health services than those who hadn't attended formal education.

Mothers who had a history of induced abortion were two times more likely to have knowledge of obstetrics fistula prevention than their counterparts. This finding is lower than the study in Burkina Faso those who had no history of pregnancy were less likely to have good awareness by $80 \%$ (10).

\section{Limitations of the evaluation}


It is very difficult to achieve in any study without drawbacks so there are possible limitations that may influence the findings while conducting this effectiveness evaluation; notably the lack of a comparable baseline study for analysis. While the design of the study attempted to address this issue by using a seven-year reference period. The post-test study design does not allow for the analysis of changes since the inception of the program. Therefore, it is not possible to definitively assume causality for differences found between women in the intervention and comparison group, many of these differences may have been pre-existing.

\section{Conclusion}

We evaluated the fistula care project with a special focus on its community-based activities to improve awareness and knowledge on obstetric fistula. This finding highlights community-level intervention can successfully increase women's knowledge of obstetric fistula. Almost more than half of women in the intervention area have good knowledge about obstetric fistula cause, and able to list at least two causes, risk, symptoms, prevention, and treatment of the condition. Thus, a significant change was apparent in the intervention area, and show that the effects may be even greater as the intervention continues. Still, there is a gap in knowledge of obstetrics fistula; therefore, it is good to scale up the intervention on providing information on safe motherhood issues, particularly about obstetrics fistula in all woredas.

\section{Abbreviations}

EmOC, Emergency obstetric care, HFE, Hamlin Fistula Ethiopia, OF, Obstetric fistula, UNFPA, United Nations Population Fund, USAID, United States Agency for International Development, VVF, Vesicovaginal fistula, WAHA, Women, and Health Alliance, WHO, World Health Organization.

\section{Declarations}

\section{Availability of data and materials}

The Evaluation data will be available upon request. Requests can be sent to zerihun.hordofa@ju.edu.et.

\section{Competing interests}

All authors have read and understood BMC publication policy on declaration of interests and have no relevant interests to declare.

\section{Acknowledgments}

We thank the United Nations Population Fund for financial support for carrying out this study. Our data collection team for their hard work to conduct the surveys. We thank Bench Sheko Zone health Department, Semen bench, and Guraferda woreda health officials, for their invaluable support in the process of the data collection.

\section{Funding}

United Nations Population Fund sponsored for data collection of this evaluation.

\section{Author information Contributions}


ZA conceptualized and designed the study and conducted the evaluation. FT, MG, and AB wrote the first draft. ZA, DA, and $A B$ drafted the final manuscript, and all authors reviewed and approved the manuscript.

\section{Corresponding author}

Correspondence to Zerihun Asefa

\section{Ethics approval}

Ethical approval and use of these evaluation data were approved by Institutional Review Broad of the Institute of Health, Jimma University. Reference number IRB00090/2020, and date 01/07/2012. Written consent was obtained from each respondents. Data collectors maintained confidentiality through excluding names or any other personal identifiers from data collection shees and reports.

\section{Consent for Publication}

No individual's details, images, or video are included such that consent to publish is not applicable.

\section{References}

1. WHO. Obstetric Fistula New. 2018; Available from https://www.who.int/features/factfiles/obstetric_fistula/en/

2. Özge Tunçalp, Vandana Tripathi, Evelyn Landry CKSSA. \{WHO\}| Measuring the incidence and prevalence of obstetric fistula: approaches, needs and recommendations [Internet]. 2017. Available from: https://www.who.int/bulletin/volumes/93/1/14-141473/en/

3. Tebeu PM, Fomulu JN, Khaddaj S, Bernis L De, Delvaux T, Rochat CH. Risk factors for obstetric fistula: a clinical review. Int Urogynecol J. 2012;387-94.

4. Hamlin Fistula USA. Obstetric Fistula in the United States. Available from: http://hamlinfistulausa.org/site/wpcontent/uploads/2015/05/Obstetric-Fistula-in-the-United-States.pdf

5. UNFPA. a [Internet]. Available from: https://www.unfpa.org/obstetric-fistula

6. Nolsøe CP. Campaign to End Fistula with special focus on Ethiopia - A walk to beautiful 1 Is there a role for ultrasound ? 2013;16(May):45-55.

7. Baker Z, Bellows B, Bach R, Warren C. Barriers to obstetric fistula treatment in low-income countries: a systematic review. Trop Med Int Heal. 2017;22(8):938-59.

8. FMOH. Strategic Plan for Elimination of Obstetric Fistula in Ethiopia by 2020 Strategic Plan for Elimination of Obstetric Fistula in Ethiopia by 2020 Federal Ministry of Health. 2015;

9. WHO. Obstetric Fistula. Guidline. 2006. p. 20.

10. Banke-Thomas AO, Kouraogo SF, Siribie A, Taddese HB, Mueller JE. Knowledge of obstetric fistula prevention amongst young women in urban and rural Burkina Faso: A cross-sectional study. PLoS One. 2013;8(12):1-8.

11. Turan JM, Tesfagiorghis M, Polan ML. Evaluation of a Community Intervention for Promotion of Safe Motherhood in Eritrea. J Midwifery Women's Heal. 2011;56(1):8-17. 
12. yenealem F, Feyisa W, Nigusie A TA. Awareness and its associated factors of obstetrics fistula among pregnant mothers attending antenatal care clinics. Matern Fetal Med. 2019;21203.

13. Banke-Thomas AO, Kouraogo SF, Siribie A, Taddese HB, Mueller JE. Knowledge of obstetric fistula prevention amongst young women in urban and rural Burkina Faso: A cross-sectional study. PLoS One. 2013;8(12):1-8.

14. Interventions CFP. FISTULA CARE Evaluation of Community-Level Fistula Prevention Interventions in Guinea. 2013; (January).

15. Azanu WK, Dassah ET, Agbeno EK, Ofori AA, Opare-Addo HS. Knowledge of obstetric fistula among prenatal clinic attendees and midwives in Mfantsiman municipality, Ghana. Int J Gynecol Obstet. 2020;148(S1):16-21.

\section{Figures}

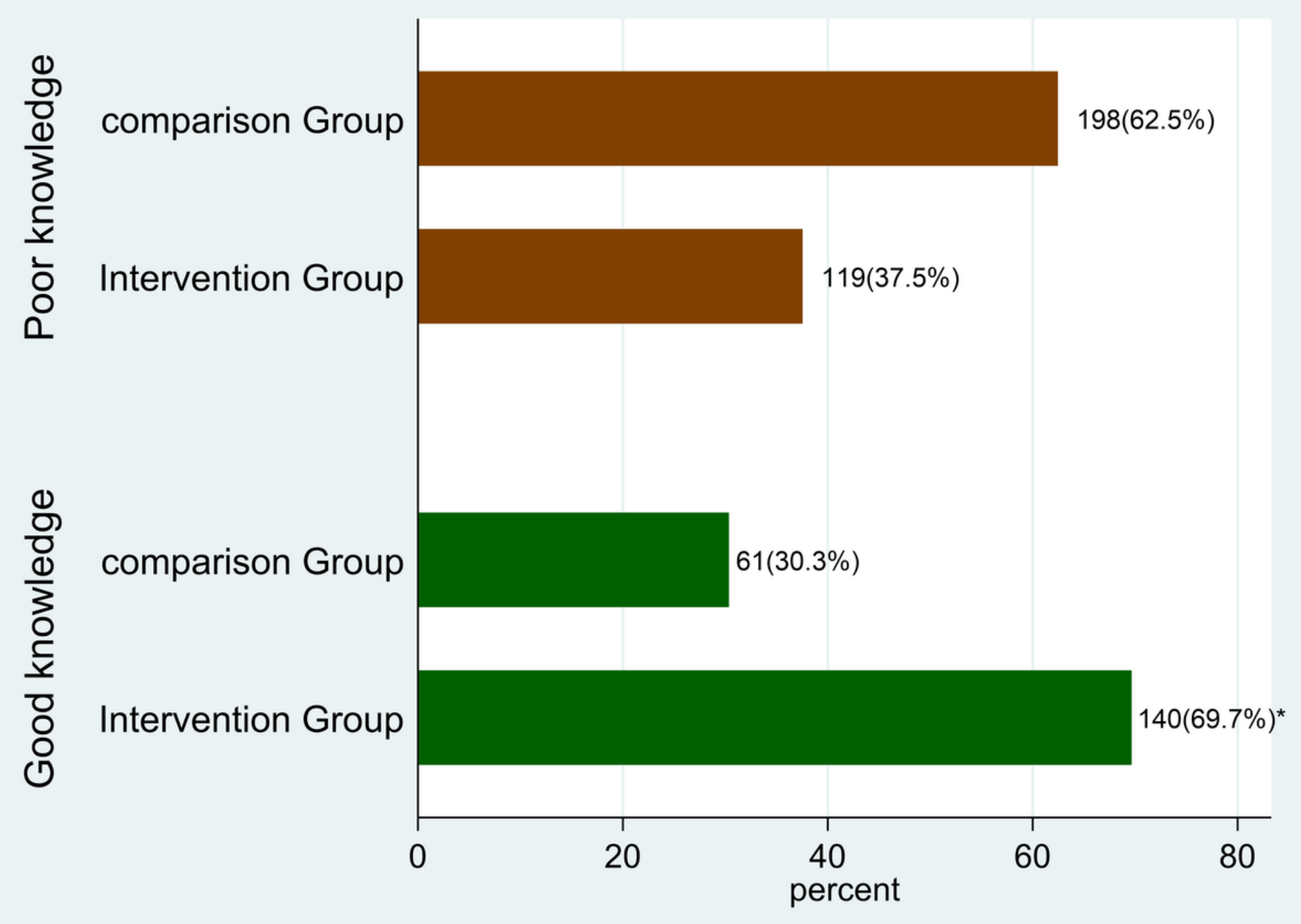

Figure 1

Overall knowledge status of women in Bench Sheko Zone, Ethiopia,2020 $(n=518)$. Chi-square test, $p<.05$ is statistically significant 